\title{
ARTICLES
}

\section{The Resilience of Democracy in the Midst of the COVID-19 Pandemic}

\author{
Democratic Compensators in Belgium, the Netherlands and \\ France
}

Tom Massart, Thijs Vos, Clara Egger, Claire Dupuy, Constance Morel-Jean, Raul Magni-Berton \& Sébastian Roché*

\begin{abstract}
Since January 2020, European countries have implemented a wide range of restrictions to contain the COVID-19 pandemic. Yet governments have also implemented democratic compensators in order to offset the negative impacts of restrictions. This article aims to account for the variation of their use between Belgium, the Netherlands and France. We analyse three drivers: the strength of counterpowers, the ruling parties' ideological leanings and political support. Building on an original data set, our results distinguish between embedded and ad hoc compensators. We find that ad hoc compensators are championed mainly by counterpowers, but also by ideology of the ruling coalitions in Belgium and the Netherlands and used strategically to maintain political support in France. Evidence on the link between embedded compensators and counterpowers is more ambiguous.
\end{abstract}

Keywords: COVID-19, crisis-management, democratic compensators, exceptionalism.

* Tom Massart is a PhD candidate at ULB / CEVIPOL. His research mainly focuses on European economic governance. Thijs Vos is a political scientist and research assistant at Groningen University. Clara Egger is assistant professor in international relations at Groningen University. She is currently leading the Exceptius project on Covid19 containment policies in Europe. Claire Dupuy is professor of comparative politics at UCLouvain. She specializes in comparative public policy with a focus on multilevel governance, federalism and regionalization processes. Constance Morel-Jean is a master's student at Grenoble-Alpes University. She specialises in the study of political behaviour. Raul Magni-Berton is professor of political science at Grenoble-Alpes University, PACTE research unit. His research mainly focuses on democracy, its institutions and norms. Sebastian Roché is CNRS Research Professor at Grenoble-Alpes University, PACTE research unit. He specializes in policing and legitimacy studies. 


\section{Introduction}

Since the outbreak of the pandemic in January 2020, European countries have taken exceptional measures to contain the spread of COVID-19. Although the stringency of policy responses varies considerably from one country to the next, COVID-19 containment measures all depart from ordinary democratic governance and restrict fundamental rights and daily liberties. The scope of the measures and their duration have sparked a great deal of media and scholarly attention (see, for a comparative account, Bjørnskov, 2020; Migone, 2020), especially as they started to be contested. Yet alongside visible and impactful restrictive measures, governments have also implemented packages of democratic compensators that aim to offset the negative consequences of the restrictions on the rule of law, democratic governance, civil liberties and daily freedoms. Democratic compensators include a diverse set of decisions and practices such as the limitation of exceptional measures in time, clauses conditioning their inclusion in ordinary law to parliamentary votes, extended delays for administrative or legal acts, and online communal councils thought of as accountability mechanisms set up to justify exceptional measures.

As such measures are designed to mitigate the disruptive impacts COVID-19 containment measures have on civil liberties and democratic processes, one could expect the use of democratic compensators to be stronger and more diverse in countries implementing particularly stringent measures. During the first wave of the pandemic, Belgium seems to have followed such a course of action as compensators were gradually implemented as measures extended over time and gained in stringency. Yet a glimpse at neighbouring countries reveals more contrasting patterns, with democratic compensators used regardless of the amount and stringency of restrictive measures. Although the Netherlands implemented minimal restrictions, democratic compensators strictly limiting the duration of the measures and enabling derogatory statuses were introduced since the first restrictive measures were adopted. In contrast, France was one of the European countries implementing the toughest regime of restrictions without compensating for them over a long time (Egger, Magni Berton, Roché \& Aarts, 2021; Terpstra, de Maillard, Salet \& Roché, 2021); and once democratic compensators were introduced, they were limited in scope and targeted specific groups.

This article attempts to account for this variation by uncovering how democratic compensators are used in emergency situations. Our objectives are threefold. First, we conceptualise the role democratic compensators play in ensuring the resilience of democratic processes and human rights during crises. Second, we map their types and uses during the COVID-19 crisis by comparatively studying Belgium, the Netherlands and France. Third, we explore the observed variation in their uses by emphasising three drivers: the strength of counterpowers, whether subnational government or opposition parties; ruling parties' preferences regarding democratic rule and political liberalism; and the level of political support where decreasing levels of support make democratic compensators more needed.

Our article builds on an original data set that maps the exceptional measures taken and implemented daily to contain the spread of the COVID-19 in 32 Euro- 
pean countries at the national and subnational levels. Our data provides a comprehensive view of exceptional decision-making in times of crisis by mapping not only restrictive measures but also compensatory decisions in various dimensions of democratic governance, the rule of law and public administration.

Our results illuminate the coexistence of two types of democratic compensators: embedded compensators, which are part of the crisis-management legal framework and predate the crisis, and ad hoc compensators, which are taken as the crisis unfolds and exceptional restrictions accumulate. We also find evidence that structural drivers, in the form of the amount and strength of counterpowers, influence the number and types of compensators used. Belgium and the Netherlands activated a wide range of embedded compensators and adopted many ad hoc compensators because their executive could not engage in crisis decisionmaking without including a broad range of parliamentary and subnational counterpowers. In contrast, in both countries, situational drivers play a more limited role. Specifically, the salience of issues of freedom, democracy and civil liberties in both countries and Belgian and Dutch ruling coalition parties' respective positioning about them also contributes to explaining the large number of ad hoc compensators recorded in both countries. In contrast, in the French case, we only find evidence of a strategic use of ad hoc compensators to fight the erosion of political support.

These results contribute new knowledge to the dynamics of crisis management and democratic resilience in emergency situations. So far, the literature on crisis management policies - especially in the wake of the COVID-19 crisis - has focused the analysis on restrictive measures (Bjørnskov, 2020; Bjørnskov \& Voigt, 2020; Capano, Howlett, Jarvis, Ramesh \& Goyal, 2020; Cheng, Barceló, Spencer, Kubinec \& Messerschmidt, 2020; Egger et al., 2021; Migone, 2020). Less attention has been paid to how such measures coexist with other types of crisis-management policies, specifically measures that aim to mitigate the indirect impacts of the crisis on democratic governance, the economy or social cohesion. As a result, we know very little about the way policymakers ensure democratic resilience in crisis situations where exceptional measures are adopted that depart from ordinary governance.

Our article is structured as follows. Section 1 presents the analytical framework of the article. Section 2 details the data and research design. Sections 3 and 4 present our empirical results, while the concluding section discusses them as well as further avenues for research.

\section{Analytical Framework: Democratic Compensators in Exceptional Times}

Although not unprecedented, the COVID-19 pandemic caught European countries largely ill-prepared. This has led governments to react in very diverse ways on the basis of a series of factors ranging from the severity of the crisis, the level of resources available and the preparedness for crisis situations. Yet, although diverse, the policy responses to the COVID-19 crisis created a state of exceptionalism that departs from the ordinary course of democratic governance and has 
been justified by the severity of the threat the pandemic poses for societies and institutions.

Exceptional decision-making implies the activation of emergency powers or the creation of an ad hoc legal order. As expected by critics of democracy, who predicted that sovereigns tend to manipulate states of exception to increase their powers (Schmitt, 1922), during the pandemic we were witnessing the implementation of policies that limit basic rights and civil liberties on the one hand, and the ability to control governments on the other. Besides sanitary measures, studies highlight what kinds of rights and freedom were taken away from the people (Bjørnskov \& Voigt, 2020), how discrimination progressed (Honigsbaum, 2020), and how the functioning of the political system departed from its formal ordinary codifications (Zanghellini, 2016). While the nature of the exceptions decided were at the core of the scholarly investigation, little attention has been given to efforts governments made to alleviate exceptional measures and to compensate for them.

This article intends to fill this gap by exploring how governments, when implementing emergency measures that destabilise a rights-based system, also aim at compensating the democratic loss of citizens. We define democratic compensators as decisions to grant exceptional rights to individuals, political and judicial institutions at national or subnational levels of government, as well as non-governmental actors, in an attempt to compensate for the negative impacts emergency measures have on civil liberties and the rule of law.

Such decisions can be twofold. First, compensators may be embedded in the dispositions regarding the activation of emergency measures in times of crises. In the French case, the law related to the sanitary state of emergency foresees that the executive can declare it for an initial period of only one month. Any prolongation needs to be decided on by parliament by means of an ordinary law. In addition, the data justifying the implementation of such an exceptional measure needs to be publicly accessible (Journal officiel, 2020). Second, compensators may originate from ad hoc decisions taken as the crisis unfolds. In this case, they do not originate from a predefined crisis-management legal framework. Such compensators have been largely implemented in Belgium and the Netherlands, with measures allowing official decision-making bodies to meet virtually and enabling electronic voting (see, for example, the amendments to its internal rules of procedure adopted by the Belgian House of Representatives on 26 March, Moniteur Belge of 02 April 2020). Our definition of democratic compensators is instrumental to a systematic study of how policymakers intend to compensate for the disruptive impacts of crisis management policies.

Our second theoretical objective is to account for the varied uses of such compensators, particularly focusing on differences in the number and type of compensators used. To explore the rationale behind such choices, we rely on the main existing rationalities of decision-making to develop three preliminary explanations. First, based on institutional accounts of decision-making, we argue that compensators emerged from a checks-and-balances process (Boin, 't Hart, Stern \& Sundelius, 2016; Lodge \& Wegrich, 2012). This process operates at two interrelated levels. First, the activation of emergency powers by governments, be they 
constitutionalised or not, nearly always implies the support of parliamentary and judicial counterpowers (Bjørnskov \& Voigt, 2018). We should hence expect embedded compensators to be shaped exclusively by the strength and number of counterpowers (Bjørnskov \& Voigt, 2018). Second, when acting out of pre-existing crisis-management mechanisms, a pre-eminent role of the government in crisis times always faces a possible veto of parliament or local government. The larger the number of veto players, the more likely it is for the government's decisions to be vetoed during an emergency (Tsebelis, 2002). To avoid such a situation, governments may strive to send reassuring signals to counterpowers by compensating for their lack of influence over crisis policymaking. In such an equilibrium, we should see the government using compensators when championed by sufficiently powerful political forces originating from the opposition, local powers or courts. As a result:

Hypothesis 1 - If counterpowers are strong and numerous, then a large number of compensators, especially embedded compensators, are introduced.

A second mechanism relates the use of democratic compensators with the ideological preferences of the ruling party or coalition. Parties in government that support human rights and civil liberties are likely to introduce mitigating measures with regard to exceptional situations where these rights and freedoms are undermined. Although studies on partisan positioning on COVID-19 containment measures in several countries report a strong rally-around-the flag effects blurring partisan divides (Louwerse, Sieberer, Tuttnauer \& Andeweg, 2021), partisan divides have remained un-blurred in other countries like the United States. In the US, the management of the pandemic was polarised along partisan lines between Republicans, first and foremost former President Trump, who called for an end to closures and restrictions, and Democratic governors who have implemented restrictive measures (see Rozell \& Wilcox, 2020). In Europe as well, there is evidence of a partisan effect. Right-wing national conservative parties - such as Fidesz in Hungary or the PiS in Poland - have implemented the toughest restrictions on democratic governance and civil liberties (Egger et al., 2021). We therefore expect parties' ideologies to shape their preference for specific uses of democratic compensators. Specifically, we expect both the salience of the issue of the protection of individual rights and liberties in party manifestos and parties' respective positioning on this issue to drive the introduction of democratic compensators.

Hypothesis 2 - If the ruling party or coalition has libertarian positions when it comes to law and order, and if this issue is salient in its manifesto, then a wide range of ad hoc compensators are introduced.

Thirdly, democratic compensators can serve an interest-based strategy and be used to avoid eroding public support. In that case, democratic compensators are introduced in an ad hoc manner when citizens are getting more critical about the exceptional measures. The introduction of compensators may thereby signal gov- 
ernments' responsiveness. Securing support for COVID-19 measures is important for electoral purposes but also to ensure compliance with exceptional measures (Bargain \& Aminjonov, 2020). As a result,

Hypothesis 3 - If governments face a decrease in political support, then ad hoc compensators are introduced.

These hypotheses are likely to complement rather than contradict each other. Also, their explanatory power with regard to both types of democratic compensators is uneven. Specifically, we expect that embedded compensators are not to be explained by the situational factors described in hypotheses 2 and 3 . Our research design aims precisely to focus on such cross-national variation to better understand the roles counterpowers, ideology and political satisfaction play in the management of a pandemic and, more largely, of any exogenous crisis.

\section{Research Design}

To map and account for the use of democratic compensators in times of crisis, we make use of an original data set, the EXCEPTIUS data set, compiling data on the exceptional measures taken daily to contain the COVID-19 crisis in the 32 countries of the European Economic Area. In this data set, each observation corresponds to a legal act adopting a diverse range of exceptional measures on a specific day and in a specific subnational region. ${ }^{1}$ Compared with concurrent data initiatives mapping governmental responses to the COVID-19 crisis (ACAPS, 2020; Hale et al., 2021), the originality of our data set lies at three levels.

First, we comprehensively map all metrics of exceptionalism, covering not only all forms of suspension of the rule of law, civil liberties restrictions and closures but also compensatory measures, derogations and exceptional authorisations. The codebook of the data set originally focuses on 8 types and 82 subtypes of events, focusing on democratic governance, the rule of law, fundamental rights and daily liberties and public administration.

Second, we collect data on the enforcement modalities of exceptional decisions. In some instances, the implementation of the measure is more important than the decision itself. In Denmark, for example, the state of emergency has been declared but was not implemented. We therefore collect data on the depth of control used in the enforcement of the measures, including information about jailing, fining, management of the policy and the military.

Third, our data includes subnational levels of government. This focus is relevant not only for regionalised or federal countries, where subnational governments or parliaments have emergency powers and a large scope of policy responsibilities, but also in unitary states, where implementation and enforcement may vary across subnational units.

Our dependent variable is an exceptional measure, either restricting or compensating for restrictions, hence allowing us to uncover the relationship between restrictive measures and the number and type of democratic compensators. Our 
data collection strategy has followed a decentralised approach. In each country, the data collection process is organised around a national team leader (or co-team leaders) and a set of coders. Team leaders and coders have been initially provided with coding rules by the coordinating entities of the project working in collaboration with a multidisciplinary board of experts. Coders were first required to identify a corpus of sources - mostly national and subnational legal archives and press conferences by the executive (see Appendix A2 for the corpus of sources). Exceptional measures were then either coded in each national data set based on the shared codebook or summarised in a comment box allowing coders to account for national specificities that were not captured by our set of original variables. For each measure, coders indicated whether it was introduced, relaxed or strengthened. Besides the identification of the measure itself, data related to the description of the event was also collected. This includes data related to the authority adopting or implementing the measure, the type of legal instrument used, the target groups of the measure and the nature and level of sanctions used in its enforcement.

To ensure the consistency of the coding process, coders met bimonthly to share questions and strengthen common standards. The final data set used in this article covers the first wave of the COVID-19 pandemic that unfolded from 30 January to 30 June 2020. We analyse patterns of democratic compensation at a time when the uncertainty was at its peak as evidence of the effectiveness of exceptional measures was low and European countries were overwhelmed by the health crisis. After coding the first wave measures, we computed a Krippendorff's alpha reliability estimate based on a sample of our data set. We obtained a score of 0.73 on the Krippendorff's alpha scale, where 0 is perfect disagreement and 1 is perfect agreement. Although this is slightly below established standards of strong intercoder reliability (where alpha $>0.8$ ), this is still a very good score given the large number of categories of our coding process. With the ambiguity of some coding rules now further clarified, we expect to reach conventional standards when coding the next waves.

Our comparative design contrasts three EU political systems - Belgium, France and the Netherlands - that display variation in the number and types of democratic compensators used and their relationship with the stringency of exceptional measures. The Belgian case is seemingly an expected case as the number of compensators and their diversity evolve with the severity of the crisis and the stringency of the measures. In contrast, its close neighbours have followed a diverse course of action. In France, where the measures were particularly stringent, democratic compensators were initially limited and mostly embedded in crisis-management policies. In the Netherlands, on the contrary, democratic compensators were introduced very early even though the Dutch government followed a rather soft approach of crisis management during the first wave.

With regard to our independent variables, the three selected countries are also characterised by a strong variation. Table 1 summarises the characteristics of each country in light of our three explanatory factors (counterpowers, ideology and political support). First, the salience and positioning of ruling coalitions and parties on freedom, human rights and democracy vary. We rely on two measures 
Table 1 Institutional and political features of country cases

\begin{tabular}{|c|c|c|c|c|}
\hline & & Belgium & $\begin{array}{l}\text { The Nether- } \\
\text { lands }\end{array}$ & France \\
\hline \multirow[t]{2}{*}{$\begin{array}{l}\text { Counterpowers } \\
\text { (CP) }\end{array}$} & Subnational CP & $\begin{array}{l}\text { High (federal } \\
\text { state) }\end{array}$ & $\begin{array}{l}\text { Low (unitary } \\
\text { state) }\end{array}$ & $\begin{array}{l}\text { Low (unitary } \\
\text { decentralised } \\
\text { state) }\end{array}$ \\
\hline & Parliamentary CP & $\begin{array}{l}\text { High (propor- } \\
\text { tional system) }\end{array}$ & $\begin{array}{l}\text { High (propor- } \\
\text { tional system) }\end{array}$ & $\begin{array}{l}\text { Low (majority } \\
\text { system) }\end{array}$ \\
\hline \multirow[t]{2}{*}{$\begin{array}{l}\text { Ideology of rul- } \\
\text { ing parties/coa- } \\
\text { lition }\end{array}$} & $\begin{array}{l}\text { Importance of } \\
\text { freedom, human } \\
\text { rights/democracy } \\
\text { (Political Manifes- } \\
\text { tos Project) }\end{array}$ & Moderate (I.43) & High (1.62) & Low (I.0I) \\
\hline & $\begin{array}{l}\text { Civil liberties vs. } \\
\text { law \& order } \\
\text { (Chapel Hill } \\
\text { Expert Survey) }\end{array}$ & Moderate (4.8) & High (5.8) & High (6.0) \\
\hline \multirow{2}{*}{$\begin{array}{l}\text { Political trust } \\
\text { (Grote Coro- } \\
\text { nastudie, 2020; } \\
\text { Kantar Survey, } \\
2020 \text {; RIVM, } \\
2021 \text {; Torcal, } \\
2017 \text { ) }\end{array}$} & $\begin{array}{l}\text { Trust in institu- } \\
\text { tions }\end{array}$ & Low & High & Low \\
\hline & $\begin{array}{l}\text { Decline in sup- } \\
\text { port for govern- } \\
\text { ment }\end{array}$ & High (> 20\%) & Low (<5\%) & High (> 20\%) \\
\hline
\end{tabular}

based, respectively, on party manifestos (Krause et al., 2020) and experts' surveys (Bakker et al., 2020). The Party Manifestos Project codes the quasi-sentences in each manifesto during the parliamentary elections. The code measures the salience of an issue, but recently party positions have also been identified. We use the data that captures both salience and party position. The Chapel Hills expert survey only measures the party positions on each issue. The measures are consistent in Belgium, France and the Netherlands. For instance, according to the Chapel Hill Expert Survey, La République En Marche (LREM), the French ruling party, prioritises law and order over individual rights, and according to the Political Manifesto coding, individual freedom displays low salience. Second, in terms of counterpowers, Belgium scores high both in terms of subnational and parliamentary counterpowers, France scores low on both - despite constitutionally being a regionalised state - while the Netherlands displays intermediate values. Last, both Belgium and France are characterised by low levels of overall political trust, even though Belgians trust their government more than the French (Torcal, 2017). In addition, public opinion surveys during the first wave reported that public belief in their government's ability to tackle the COVID-19 crisis decreased sharply between March and June 2020 in both countries, while Belgians are ultimately more satisfied with COVID-19 measures than the French (Decker, 2020; Grote Coronastudie, 2020; Kantar Survey, 2020). In the Netherlands, in contrast, trust is high, and the support for government's action did not significantly change over the period under study (RIVM, 2021). 
Our sample size and the nature of our data only allow for a descriptive and exploratory approach. Our design, however, sheds light on a neglected aspect of crisis management policies and documents the diversity of tools policymakers use to compensate for democratic and liberties loss in times of crisis. To account for the observed variation, we relate each pattern to defining characteristics of each political system derived from our conceptual framework. We focus on variation between countries and do not study the role of policy transfers and diffusion.

\section{Descriptive Analysis: Exceptional Measures and Democratic Compensators Compared}

Our data shows that two types of compensators were introduced during the first wave of the COVID-19 pandemic. Their key difference is conceptual and lies in their timing of adoption: whether their origin predates the crisis or whether they were adopted in an ad hoc manner during the crisis. Embedded democratic compensators are established in constitutional texts, crisis-management legal framework, as well as in emergency planning related documents. They therefore predate the occurrence of a crisis, in this case the COVID-19 pandemic. Examples include the obligation to set a time limit to the delegation of emergency powers to executives, the authorisation by a parliamentary vote of executives' exceptional orders, the extension of procedural deadlines and limits of recourse in judicial and administrative proceedings.

Ad hoc democratic compensators pertain to decisions accompanying restrictions taken as the crisis unfolds. They are included in acts restricting basic and civil liberties or in independent laws adopted as supplements to restrictive measures. Compared with embedded democratic compensators, they hinge on the specific context of a given crisis. Authorisations of virtual decision-making and postponement of general assemblies, counterbalancing lockdowns and restrictions of movement, are cases of ad hoc democratic compensators. In the judiciary, the introduction of virtual court sessions as a reaction against the inability due to the pandemic to organise public hearing is another instance of ad hoc democratic compensators.

Table 2 offers an overview of the scope and types of compensators adopted during the first wave in Belgium, the Netherlands and France. Two findings stand out: first, embedded compensators are associated mainly with crisis decisionmaking and the operation of the judiciary. In all three countries, they mainly take the form of time limits to acts restricting civil liberties or measures challenging acts restrictive of civil liberties. Subjecting emergency measures to a parliamentary vote is another embedded democratic compensator in place in Belgium and France. Similarly, regarding the judiciary, in all three countries, the highest court was consulted to check for the legality of emergency acts. In Belgium and France, legal continuity was ensured through emergency rulings organised even as courts were closed.

In contrast, the scope of ad hoc democratic compensators and their association with general processes of decision-making and the operation of the 
legislative branch are unexpected observations. In the three countries, procedural deadlines were extended, oaths were allowed to be sworn in writing or digitally and subnational governments' decision-making bodies were allowed to convene virtually. Regarding the legislative branch, electronic and distant voting procedures were allowed. In addition, ad hoc democratic compensators are also associated with participation rights of citizens, civil society as well as decision-making of associations and companies. E-tools were set at the subnational level in the three countries as well as measures guaranteeing freedom of association.

Besides this crucial difference, the introduction of democratic compensators, whether embedded or ad hoc, varies across Belgium, the Netherlands and France at two main levels. First, in terms of number and scope, Belgium and the Netherlands adopted more compensatory measures than France. Also, the democratic compensators introduced in Belgium and the Netherlands do not discriminate against any target groups, while France has introduced compensators aimed at targeted audiences, such as students. In Belgium, restrictive measures and compensators were taken in the context of the emergency framework such as the granting of special powers to executives and the obligation to set up a time limit. Additional ad hoc compensators were taken during the crisis such as amendments to parliamentary procedures (allowing online voting). The Netherlands adopted compensators during the pandemic in different areas such as in the judiciary (virtual sessions allowed), private sector and civil society (virtual decision-making, early voting, postponement of general assembly). France took fewer ad hoc compensatory measures, essentially after having decided on restrictions. Several compensators were, however, already embedded in the state of emergency legal provisions such as the right to protest that was further reaffirmed by the council of state at the end of the first wave. In contrast, the Netherlands has fewer embedded compensators.

Table 2 The compensators per type of category (embedded or ad hoc) for Belgium, the Netherlands and France

\begin{tabular}{|c|c|c|c|}
\hline & Belgium & The Netherlands & France \\
\hline \multicolumn{4}{|l|}{$\begin{array}{l}\text { General decision- } \\
\text { making }\end{array}$} \\
\hline $\begin{array}{l}\text { Extension of proce- } \\
\text { dural deadlines }\end{array}$ & Ad hoc & Ad hoc & Ad hoc \\
\hline $\begin{array}{l}\text { Extension of recourse } \\
\text { deadline/extension of } \\
\text { prescription periods } \\
\text { (justice) }\end{array}$ & Ad hoc & Ad hoc & Ad hoc \\
\hline $\begin{array}{l}\text { Extension of validity of } \\
\text { certificates, licences } \\
\text { (e.g. technical inspec- } \\
\text { tion for cars, driving } \\
\text { licences) }\end{array}$ & Ad hoc & & Ad hoc \\
\hline $\begin{array}{l}\text { Online consultation of } \\
\text { documents is allowed }\end{array}$ & Ad hoc & Ad hoc & Ad hoc \\
\hline
\end{tabular}


Table 2 (Continued)

\begin{tabular}{lll}
\hline \multicolumn{1}{c}{ Belgium } & The Netherlands & France \\
\hline $\begin{array}{l}\text { Oaths can be sworn in Ad hoc } \\
\text { writing or digitally }\end{array}$ & Ad hoc & Ad hoc \\
$\begin{array}{l}\text { Virtual sessions of offi- Ad hoc } \\
\text { cial decision-making }\end{array}$ & Ad hoc & Ad hoc \\
$\begin{array}{l}\text { body (municipality } \\
\text { councils, provincial } \\
\text { councils, etc). }\end{array}$ & & \\
\end{tabular}

\section{Crisis decision- making}

Motivation of acts restricting civil liber-

ties

Time limits in acts restricting civil liberties

Legal regime of emer- Embedded gency measures (subject to parliamentary vote in order to become permanent)

The ability of challeng- Embedded ing acts restricting civil liberties

Revoking of criminal records for those who violated COVID measures

Mayoral dispensation powers introduced (TWM act)

\section{Legislative branch}

Implementation of electronic voting procedures (national legislature and subnational assemblies)

Question hour on COVID-19 in (decentralised) legislature(s)

Ad hoc
Embedded

Embedded

Embedded

Embedded

Embedded

Embedded

Embedded

(Second wave)

(Second wave)
Embedded

\section{Judicial branch}

Introduction of virtual Ad hoc

Embedded court sessions (ensur-

ing continuity and publicity)

Consultation of higher Embedded courts for the legality

Embedded 
Table 2 (Continued)

The closure of the
high courts does not
prevent them from
emergency rulings or
minimum service
Other public organ-
isations

Virtual meeting of Jean, Raul Magni-Berton \& Sébastian Roché
Erance
Embedded
Ad hoc
Embedded
Ad hoc

public organisations

Belgium

The Netherlands Jean, Raul Magni-Berton \& Sébastian Roché
Erance
Embedded
Ad hoc
Embedded
Ad hoc

(ensuring continuity and publicity)

\section{Civil Society}

Authorisation of virtual decision-making for private legal entities (companies, notfor-profit foundations, associations)

Measures guaranteeing Ad hoc freedom of association (postponement of general assemblies)

Right of information for members of associations and stakeholders of private companies

Early voting introduced for general meetings of associations and private companies

\section{Citizens' participa-}

tion

More extensive use of Ad hoc 'e-tools' in citizens' participation in local government

\section{Other}

Suspension of (unfin- Ad hoc ished) public inquiries

Measures ensuring the Ad hoc continuity of health and government services (hiring of personnel: lowering of the required qualifications, police mobilisation, etc.) Jean, Raul Magni-Berton \& Sébastian Roché
Erance
Embedded
Ad hoc
Embedded
Ad hoc Jean, Raul Magni-Berton \& Sébastian Roché
Erance
Embedded
Ad hoc
Embedded
Ad hoc Jean, Raul Magni-Berton \& Sébastian Roché
Erance
Embedded
Ad hoc
Embedded
Ad hoc Jean, Raul Magni-Berton \& Sébastian Roché
Erance
Embedded
Ad hoc
Embedded
Ad hoc Ad hoc

Ad hoc

Ad hoc

Ad hoc
Ad hoc
Ad hoc

Ad hoc Ad hoc

Embedded

Ad hoc

Ad hoc 
Figure 1 Timing of democratic compensators during the first wave in Belgium, the Netherlands and France

In terms of the timing of the adoption of ad hoc democratic compensators (see Figure 1), two patterns are visible. In the Netherlands, most of them were adopted in April, when cases peaked. In contrast, in Belgium and France, most ad hoc compensators were introduced earlier on, in March and early April. Strikingly, almost none of the countries studied introduced democratic compensators in May and June as measures were relaxed at the end of the first wave.

\section{Democratic Compensators Explained: The Role of Counterpowers, Ideology and Public Support}

To further account for cross-national variation in patterns of democratic compensation, we relate such patterns to three key characteristics of the countries under study: the strength and number of counterpowers, the ideology of the ruling party or coalition and the level of support for the government.

\subsection{Democratic Compensators as a Tool of Counterpowers}

Our first explanation argues that democratic compensators are championed by counterpowers. If this explanation holds, we should observe, first, that democratic compensators are more numerous and diverse in systems where counterpowers are strong. This is particularly the case of embedded compensators that predate the COVID-19 crisis. Second, compensators should be primarily adopted by counterpowers, be they parliamentary or subnational. Our data provides some support for this explanation, and we report a stronger use of democratic compensators, including embedded ones, in systems characterised by strong power-sharing arrangements.

First, we observe that compensators are more numerous and diverse in political systems where the executive needs to engage with a wide range of opposition parties and subnational authorities to decide on exceptional COVID-19 containment measures. The Netherlands records a large number of compensators 
with a total number of seventeen, among which $28 \%$ are embedded ones. In our country selection, the Dutch executive had the lowest room for manoeuvre before the crisis broke out. Since late 2017, the Netherlands has been ruled by a coalition government consisting of the conservative-liberal VVD (the party of Prime Minister Mark Rutte), the Christian-democratic CDA, the progressive-liberal D66 and the small religiously conservative, centrist Christian Union. At the start of the Rutte cabinet, also referred to as Rutte III, the coalition had a very slim majority in both the lower house (Tweede Kamer) and the higher house/senate (Eerste Kamer) of, respectively, 76/150 and 38/75. Parliamentary minorities have limited counterpowers (i.e. no filibuster), the committee system is weak (Mickler, 2017) and coalition agreements are tight (Moury \& Timmermans, 2013; ROB, 2017). Formally, then, counterpowers are relatively weak. However, during the 2019 senatorial elections, ${ }^{2}$ the coalition lost its majority in the senate. The latter has a somewhat distinct position compared with other higher houses: the senate has full veto power on new legislation, but it is still disputed whether the government is dependent on the senate for confidence (de Vries, 2000). The Rutte III cabinet thus changed from a minimum-winning majority cabinet to a minority cabinet that requires the support of at least one 'large' opposition party or multiple of the smaller opposition parties to pass legislation, including on budgetary matters (Otjes \& Louwerse, 2021). In practice, the cabinet has tried to form ad hoc legislative coalitions with different opposition parties. As the Netherlands has an extensive pre-existing crisis management structure, the government could introduce measures on the basis of existing laws (in particular, the public health act, 2010, and the security region act, 2008) by giving mandatory instructions to the security region chairmen to introduce a specific measure. Compensators, however, mostly required the passing of ad hoc laws to be introduced. Exceptional measures, whether restrictive or compensatory, are enacted and implemented by the security regions' chairmen, but the general lines of the measures are set by the government. As a result, the emergency decrees of the security regions' chairmen did not differ in a substantial sense. It should be noted, however, that the government closely cooperated and consulted with the security regions' chairmen before and during the introduction of measures either in the Veiligheidsberaad (which consists of the 25 security region chairmen) or by inviting the chair of the Veiligheidsberaad to the council of ministers. Note that the security region chairmen are affiliated with both coalition and opposition parties and are often mayors of municipalities in which opposition parties form the majority (see Figure 2). Though no formal accountability system exists at the security region level, several security region chairmen introduced informal ways to consult with and account to municipal councils (or vice versa).

The contrast with France is striking. France has been ruled since 2017 by an oversized coalition in which the party of President Macron - LREM - has the majority of seats (53\%). In the lower chamber (Assemblée nationale), therefore, the other parties have little ability to oppose the government. They can do so in the higher chamber (Sénat), where the parties supporting the government are a minority. 


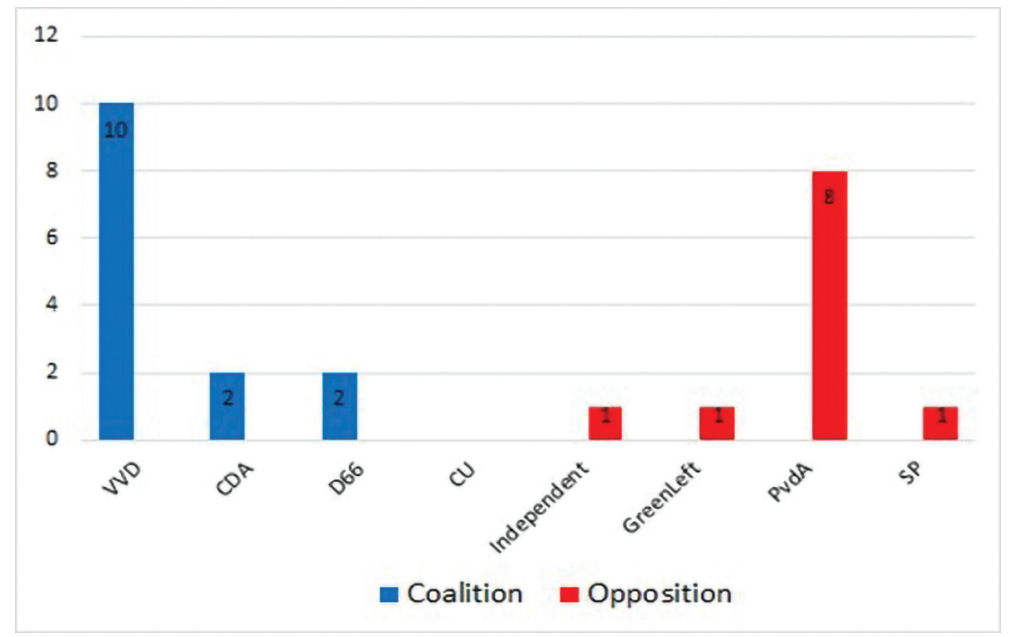

Figure 2 Party affiliation of security regions' chairmen

However, and contrary to the Dutch case, this counterpower is low because, on the one hand, the senate has fewer veto powers than the National Assembly and, on the other hand, the government can rule using ordinances that can be overturned only by a law, which requires a majority in both Chambers. The COVID-19 crisis has been largely managed by ordinances, leading opposition parties to be unable to oppose any decision. Beyond parliamentary ones, other counterpowers are also low, especially subnational governments. In France, the authority of subnational governments is comparatively lower than in Belgium (Hooghe et al., 2016). Almost the entire management of the pandemic, especially during the first wave, was controlled by the national government. This political set-up may explain why democratic compensators are rarer in France. In contrast, France records the largest number of embedded compensators despite having such a low number of counterpowers.

Belgium somehow appears as an intermediary case as the structure of decision-making during the first wave did not match that of the allocation of formal power. Belgium features a high level of regionalisation where subnational levels of government enjoy a large degree of self-rule (Hooghe et al., 2016). Yet crisis management policies granted the federal government a large measure of autonomy. This autonomy is, however, associated with a large number of compensators that are embedded into crisis-management provisions. Belgium records $32 \%$ of them. Yet because of the political situation in the country at the start of the pandemic, subnational governments and most opposition parties were fully involved in crisis decision-making from the inside as members of the National Security Council. They took part in the meetings of the main decision bodies, named the 'Kern', and of the National Security Council. Alongside the federal parliament, most subnational entities granted exceptional powers to their respective governments. Flanders is the exception but nonetheless adopted a state of emergency. This unique set-up is explained by the specific political situation Bel- 
gium was caught in when the pandemic broke out. In March 2020, no federal government with full authority was in place. The caretaker government in place during this time had the support of 38 out of 150 seats in the House of Representatives. Facing the spread of COVID-19, a large coalition of parties voted the confidence to the sitting government to deal with the crisis. The coalition included all French- and Dutch-speaking parties with the notable exception of the conservative and the radical-right Flemish parties, the N-VA and the Vlaams Belang as well as the radical left PTB/PVDA. The coalition granted the federal government special powers at the end of March (see Bouhon, Jousten, Miny \& Slautsky, 2020). Yet the agreement restricted Wilmès first cabinet's scope for action to pandemic management. Following this decision, all supporting parties in addition to the $\mathrm{N}-\mathrm{VA}$, which voted in favour of granting special powers, were included in the committee in charge of managing the pandemic (Faniel \& Sägesser, 2020). The parties were represented by their presidents and, in the case of the N-VA, the group leader at the House. This specific political set-up may explain the large number of compensators (19) recorded for Belgium.

Second, the role of counterpowers in democratic compensation is also reflected by the fact that when compensators are introduced they mostly originate from counterpowers themselves, either at the subnational or at the parliamentary level. Here again, the Netherlands appears as a typical case of compensators championed by counterpowers. When the pre-existing framework did not provide for embedded compensators, ad hoc compensators were mostly introduced by parliament. Some municipalities also came up with compensators. Although they were not rooted in law, the same consensual decision-making can be found in the Belgian case, where one third of democratic compensators adopted during the first wave of COVID-19, and specifically on 13 March, were embedded in the Royal decree of January 2003. This decree was designed as a general procedure for the operational coordination at the national level in crisis settings. Similarly, most of the ad hoc democratic compensators, introduced in March and April, were decided at the federal level. Yet all the measures were discussed and decided on within the National Security Council, which included the heads of subnational governments, the regions and the communities, alongside members of the federal government. ${ }^{3}$ Democratic compensators were thereby decided on at the federal level in close coordination with subnational governments. In France, most of the compensators were introduced by the government, and specific ministries (City and Housing, Higher Education, Solidarity and Health), through decrees activating the provisions of crisis-management provisions predating the COVID-19 crisis. Only two of them can be considered to be related to counterpowers. One ad hoc compensator was introduced following an injunction decision (référé) of the council of state, and another, free parking, was later introduced via municipal decrees in several cities.

All in all, our data suggests that democratic compensators are particularly used in systems where counterpowers are strong and diverse, for either institutional or situational reasons. Interestingly, based on their checks and balances structure, we would have expected Belgium to record a larger number of compensators and France a lower one than what was actually adopted and introduced 
Table 3 Ideology of ruling party/coalition

\begin{tabular}{lllll}
\hline & $\begin{array}{l}\text { Freedom } \\
\text { (Party Mani- } \\
\text { festo) }\end{array}$ & $\begin{array}{l}\text { Human Rights } \\
\text { (Party Mani- } \\
\text { festo) }\end{array}$ & $\begin{array}{l}\text { Democracy } \\
\text { (Party Mani- } \\
\text { festo) }\end{array}$ & $\begin{array}{l}\text { Civil liberties } \\
\text { vs. Law \& } \\
\text { Order (Chapel } \\
\text { Hill Survey) }\end{array}$ \\
\hline $\begin{array}{l}\text { Belgium (aver- } \\
\text { age score) }\end{array}$ & 1.47 & 1.55 & 1.28 & 4.88 \\
$\begin{array}{l}\text { France (LREM) } \\
\begin{array}{l}\text { The Nether- } \\
\text { lands (average } \\
\text { score) }\end{array}\end{array}$ & 0.83 & 0.98 & 1.93 & 6.0 \\
\hline
\end{tabular}

Legend: percentage averages of the statements (quasi-sentences) contained in the electoral programmes of the ruling parties concerning freedom, human rights and democracy (Manifesto Project Database). Average scores of governing parties by country on their position on civil liberties $(=0)$ versus law and order $(=10)$ using Chapel Hill Survey data. High scores are in bold and low scores are in italic.

(Source: Manifesto Project Database, Chapel Hill Expert Survey)

during the first wave. As in France, a large number of embedded compensators are recorded, suggesting perhaps that counterpowers better explain ad hoc compensators than embedded ones. Yet it should also be noted that Belgian subnational governments introduced only a few, and mainly informal, ad hoc compensators.

\subsection{Are Democratic Compensators Introduced for Ideological Reasons?}

Our second explanation argues that the introduction of ad hoc democratic compensators reflects the ideological leaning of the ruling party or coalition. We rely on data from the Manifesto Project that describes the salience of a broad range of topics in party manifestos, as well as parties' policy positions based on a content analysis of parties' electoral manifestos in the last national election (Krause et al., 2020). We selected three topics that are particularly relevant for our focus on democratic compensators: 1 . Freedom (Favourable mentions of the importance of personal freedom), 2. Human Rights (Favourable mentions of the importance of human and civil rights), 3. Democracy (Favourable mentions of democracy minus the statements against the idea of democracy). We expect that high scores on these dimensions result in a stronger use of ad hoc compensators in times of crisis. Since this variable concerns a single topic in a manifesto that includes many more issues, even a $0.2 \%$ difference should be regarded as significant. We also compare this score with the scores provided by the 2019 Chapel Hill Expert Survey on the positioning of political parties on the dimension 'civil liberties vs. law and order', which measures whether parties strongly favour civil liberties (0) or strongly favour strong measures to fight crime (10). The Chapel Hill Expert Survey provides information about the positions of 277 parties on various policy areas in 32 countries. The survey was administered in Winter 2020 and completed by 421 political scientists specialised in political parties and European integration (Bakker et al., 2020). Table 3 presents the score of the ruling party or the average score of the ruling coalition in our three cases. ${ }^{4}$ 
Freedom, human rights and civil liberties are salient in the party manifestos of the ruling coalition in the Netherlands, and on average the coalition parties prioritise civil liberties almost as much as law enforcement. This is consistent with the adoption of a large number of ad hoc compensators. This is also consistent with the timing of freedom limitations, introduced the latest in the Netherlands in comparison with Belgium and France. However, there is a large variation between individual party members of the coalition. This calls for combining this ideological explanation with the structural, counterpowers-related, explanation discussed in the previous section. In the case of Belgium, these issues are not only salient for several of the French-speaking and Dutch-speaking parties supporting the government, but their positions also lean towards a larger support to individual freedoms. Crucially, although the then-sitting Wilmès government included mostly centre-right-wing parties that tend to favour law and order, it depended on these parties' support to stay in power. Thereby, when combining ideology and counterpowers, the Belgian data provides some support to hypothesis 2. Last, in France the ruling party prioritises law and order over individual rights, and human rights and freedoms are less salient in its manifesto. This is in line with the relatively small number of ad hoc compensators of our sample. The Manifesto Project data indicates, however, that LREM scores high on democratic values, in contrast to the low scores on freedom and human rights. This should predict specific compensators related to political rights. Yet we do not observe such compensators in France. Therefore, the case of France does not support our second hypothesis.

One could argue that political manifestos do not correctly translate real preferences because they also reflect a strategic use of messages. To further analyse the importance of ideological drivers, we also examine their connection with the timing of introduction of ad hoc compensators. Our reasoning is as follows: if compensators reflected genuine preferences regarding democratic rule and political liberalism, they should accompany the introduction of the first restrictive measures. Among the ten ad hoc compensators initiated by the French government, eight were introduced at the beginning of the crisis (respectively 2, 12 and 14 days after the first lockdown). Two other compensators appear from the middle of the first wave (mid-April) and one after the end of lockdown. In the Netherlands, compensators were introduced early and simultaneously with restrictive measures, hence reflecting a strong attachment to freedom and human rights since the early stages of the crisis. As for Belgium, during the months of March and April, 13 ad hoc compensators were introduced. Thus, contrary to the Netherlands and Belgium, France did not introduce ad hoc democratic compensators at the same time as the restrictions. However, as for Belgium and like the Netherlands, the majority of French ad hoc democratic compensators were introduced early in the first months of the first wave.

Overall, our analysis suggests that ideological drivers may explain some variation in the patterns of democratic compensation introduced during the COVID-19 pandemic, once the counterpowers are taken into account. However, this explanation is not supported in the case of France. 


\subsection{Democratic Compensators as Mitigation Measures for Political Support Erosion}

A last explanation considers that ad hoc democratic compensators are introduced as a mitigation measure for eroding political support. In this sense, they offset not only democratic and human rights loss for citizens but also political loss for decision makers. If this explanation holds, we should see ad hoc compensators to be introduced when the level of support for the government decreases. We relate patterns of ad hoc compensation with survey data on levels of political support before, during and after the crisis.

Overall, we do not see a clear pattern of association. First of all, everywhere in Europe, the level of support for the action of national governments was high, reflecting a rally around the flag effect typically observed in other types of crises (Louwerse et al., 2021). Second, in our sample, only France displays some evidence of a relationship between a decrease in political support and an activation of compensators. The level of approval for the action of the government fell dramatically between mid-March, when $61 \%$ of people approved the way the government managed the pandemic, and mid-April, when only $43 \%$ continued to do so. At the end of May, the approval level was at 41\% (Kantar Survey, 2020 consistent with other surveys from IFOP, Cevipof \& Harris Poll all conducted in 2020). This decrease is followed by the introduction of new ad hoc democratic compensators by the government on 15 and 23 April, which, interestingly, suggests their strategic use by decision makers. Also, in contrast to the situation in Belgium and the Netherlands, ad hoc democratic compensators in France aimed at specific target populations, as opposed to the general public, their effect was limited over time, and they focused on financial assistance. The sole democratic compensator that pertains to a universally applicable right, the right to demonstrate, was introduced by a counterpower, the council of state, in July 2020. In the French case, thereby, the introduction of ad hoc democratic compensators can be understood as mitigating measures in the face of eroding public support.

The uses of ad hoc democratic compensators in the Netherlands and Belgium do not reflect a similar pattern. In the Netherlands, the level of trust and public satisfaction with the sitting cabinet was high (around 67\% are satisfied with the cabinet, according to Driessen \& Heinkade, 2021), and large majorities supported the introduction of restrictive measures and limitations on liberties, according to Eurobarometer data 2020). Repeated surveys show that public support for the government's handling of the pandemic was consistently high: at the start of the pandemic (17-24 April), the level of trust was 73.3\%, decreasing slightly to $68.6 \%$ in the middle of the first wave (27 May- 1 June) before recovering to $72.7 \%$ after the first wave ended (8-12 July) (RIVM, 2021). These observations do not match our expectation that eroding public support would result in the introduction of more ad hoc democratic compensators.

In Belgium, at the beginning of April, almost $75 \%$ of the Belgians trusted the federal government to handle the pandemic ( 5 to 7 on a scale from 1 to 7 ). In May (26/05) and June (30/06), it fell to under 50\% (De Grote Coronastudie, University of Antwerp). Also, in May 2020, an opinion poll conducted on a representative sample of Belgians indicated that one in two Belgians was satisfied with the measures taken (Decker, 2020, Survey from Kantar - Le Vif/l'Express - Knack 
- LN24, May 2020); in June 2020, 68\% of Belgian respondents declared that the restrictions of freedom were fully justified (Zalc, \& Maillard, 2020). Interestingly, while public support decreased, no ad hoc compensators were introduced at that time. In addition, during the same period, almost half of Belgian respondents expressed their dissatisfaction regarding the structure of the Belgian state and the obstacles it raised for crisis management (Decker, 2020, Survey from Kantar Le Vif/l'Express - Knack - LN24, May 2020). These observations could suggest that because of blurred lines of responsibility in a multilevel system of government, the Belgian federal government did not act on somewhat eroding support.

\section{Discussion and Conclusion}

Departing from the literature's exclusive focus on restrictive measures, this article aimed at shedding new light on patterns of democratic compensation in times of crisis. Our contribution is twofold. First, we conceptualise what democratic compensators are and how they relate to exceptional restrictions during crises. Our analytical framework allows us to identify two types of compensators, embedded and ad hoc. In our sample, the Netherlands not only exhibited the highest level of legal preparedness to crises but also embedded mechanisms aiming to ensure democratic resilience. The second type - ad hoc compensators refers to decisions taken as the crisis unfolds to mitigate the negative impacts of exceptional decision making on democratic processes and the rule of law. Their wide use in our sample reflects that, overall, Belgium, France and the Netherlands were largely unequipped to manage the pandemic and deal not only with its direct impacts but also with its indirect impacts on social cohesion, the rule of law and democratic governance. We already see that governments have learned some lessons from this initial experience and are engaging in more diverse forms in democratic compensation in the second wave. In France, the crisis-management approach has followed a more decentralised approach, while the Dutch-amended corona act grants stronger veto powers to the lower house and creates formal accountability mechanisms at the national and local levels. Finally, the Belgian parliament is preparing a new legal framework in 2021 to deal with the crisis in the long term. Overall, our data reflects varied compensating practices, in terms of timing, scope and focus.

Second, we accounted for the observed variation in the uses of democratic compensators. Table 4 summarises our key findings.

Our analytical argument emphasises the importance of two types of drivers structural, which link patterns of democratic compensation with the institutional characteristics of a country, and situational, which are related to the ideological leaning of the ruling party or coalition and public support. In a context where a large stream of literature on crisis governance emphasises the impact of situational factors (for a review, see Ansell, Boin \& 't Hart, 2014), our results suggest that structural drivers strongly determine the ability of a political system to withstand external shocks. Systems characterised by weak and limited counterpowers are the most vulnerable to democratic and human rights loss when a crisis hits. 
Table 4 Summary of the research findings

\begin{tabular}{|c|c|c|c|}
\hline & $\begin{array}{l}\text { The higher the num- } \\
\text { ber of counterpowers, } \\
\text { the higher the number } \\
\text { of compensators and } \\
\text { more prevalent } \\
\text { embedded ones. }\end{array}$ & $\begin{array}{l}\text { The stronger the } \\
\text { emphasis of the ruling } \\
\text { coalition/party on civil } \\
\text { liberties, the larger the } \\
\text { number of ad hoc } \\
\text { compensators. }\end{array}$ & $\begin{array}{l}\text { The sharper the } \\
\text { decline in political sup- } \\
\text { port, the larger the } \\
\text { use of ad hoc compen- } \\
\text { sators. }\end{array}$ \\
\hline Belgium & $\begin{array}{l}\text { Supported for parlia- } \\
\text { mentary counterpow- } \\
\text { ers. } \\
\text { Less supported for } \\
\text { subnational counter- } \\
\text { powers. }\end{array}$ & $\begin{array}{l}\text { Supported, when } \\
\text { counterpowers are } \\
\text { taken into account. }\end{array}$ & Not supported. \\
\hline France & $\begin{array}{l}\text { Supported for ad hoc } \\
\text { compensators. } \\
\text { Not supported for } \\
\text { embedded compensa- } \\
\text { tors. }\end{array}$ & $\begin{array}{l}\text { No clear evidence in } \\
\text { support. }\end{array}$ & Some evidence. \\
\hline The Netherlands & Supported. & Supported. & Not supported. \\
\hline
\end{tabular}

This finding holds specifically in the case of France, which, despite being a longestablished democracy, has experienced among the most stringent restrictive measures in Europe, together with Hungary and Poland (Egger et al., 2021). In contrast, the Netherlands was much less vulnerable owing to its power sharing arrangements. The Belgian case suggests that counterpowers are not only a matter of formal institutional arrangements, but also of political culture. At the start of the crisis, the fractionalisation of the country resulted in a minority government supported by a national unity coalition (with the exception of some radical parties and the Flemish nationalists), allowing parliamentary and subnational counterpowers to discuss and decide on the exceptional measures needed to contain the COVID-19 pandemic. However, the former seem to have influenced crisis-management policies more than the latter. Although our study has examined only a limited number of cases, it is consistent with findings from other studies focusing on many more countries and showing that long-term drivers (such as a country's level of political trust, power sharing arrangement and financial capacities) strongly influence the level of stringency of COVID-19 containment measures (see, for example, Bargain \& Aminjonov, 2020; Egger et al., 2021). This suggests that our findings could be generalised to other long-established democracies. Reinforcing the ability of democracies to be resilient to crises may entail the development of structural reforms, strengthening counterpowers at the parliamentary and subnational levels.

In contrast, our two other explanations - focusing on ideological preferences and political support - receive a lower level of support. We find evidence consistent with the hypothesis of an influence of the coalition's ideology in France, Netherlands and Belgium, but for the latter two, this influence can be observed only after taking into account the impact of counterpowers. This may suggest that crisis management policies are little politicised in the initial stages of the cri- 
sis. The 'rally round the flag' phenomenon tends to blur ideological divides and lead to the prevalence of other, more structural, drivers. Further confirming and generalising this result would, however, require analysing a more diverse set of countries and a closer look at the ideological justifications of COVID-19 policies.

Last, our research provides some evidence of a strategic use of ad hoc compensators to mitigate a loss of political support, especially in majoritarian countries like France. This finding is, however, likely to be shaped by the time frame of our analysis. The first wave of the COVID-19 pandemic has shown high levels of political support that have sharply declined as measures were extended in time. The management of the second wave of the crisis could yield interesting insights on this aspect, especially as elections are scheduled in the Netherlands and France in 2021 and 2022. Dutch elections were scheduled to occur about a year after the first wave of the pandemic, and this timing could contribute to explaining the number of democratic compensators introduced on the issue of political rights. It may be that the large number of democratic compensators introduced during the first wave, along with only a few restrictive measures, have benefited the ruling coalition from an electoral point of view. While an electoral rally-around-the-flag is still debated, the seat share of the prime minister's party (VVD) and the coalition marginally improved (resp. 1 and 2 seats), which could be understood as a success in light of incumbents' large electoral loss in previous elections. In France, the restrictive measures were stringent, and the democratic compensators were only a few. While national elections are planned to be held later (2022), municipal elections took place during the first wave, and regional elections occurred one year later. In both cases, the party in charge lost. At this stage, therefore, the electoral impact of democratic compensators and the severity of measures are unknown, but our data will allow assessing it in the coming months.

Our results further document the proximity of the Low Countries when compared with neighbouring countries. France has followed a very distinct course of action when compared with Belgium and the Netherlands. Although our data do not allow us to trace patterns of policy diffusion, our article reports that uses of democratic compensation in the region follow similar patterns, even in countries displaying distinct institutional features.

Overall, we believe this exploratory analysis calls for more research on how policymakers compensate for the democratic loss engendered by emergency decision-making. When opting for specific policy responses to crises, policymakers face multiple trade-offs, one of which is the need not to be attacked for using the crises to strengthen authoritarian rule and their own powers. Compensators may be used to rally counterpowers and citizens around emergency measures.

\section{Notes}

1 Subnational regions are identified using the Nomenclature of territorial units for statistics (NUTS) level 2, which focuses on 'basic regions for the application of regional policies'. This classification has been slightly adapted in the case of the Netherlands to cover security regions. 
2 The senate is elected not through a popular election but by provincial deputies (in one class) who are popularly elected two months earlier.

3 Permanent members of the National Security Council are the prime minister, the deputy prime ministers and the ministers in charge of the interior and foreign affairs and defence.

4 We relied on a simple unweighted average to estimate the average score of the Dutch and Belgian coalition on freedom, human rights and democracy. We did not consider the size of each party as this does not automatically mean their bargaining power over COVID-19 containment policies is stronger.

\section{References}

ACAPS. (2020). COVID-19: A Global Joint Response. Retrieved from www.acaps.org/ projects/covid-19.

Ansell, C., Boin, A. \& 't Hart, P. (2014). Political Leadership in Times of Crisis. In R.A.W. Rhodes, \& P. 't Hart (Eds.), The Oxford Handbook of Political Leadership. Oxford: Oxford University Press.

Bakker, R., Hooghe, L., Jolly, S., Marks, G., Polk, J., Rovny, J., ... Vachudova, M. A. (2020). 1999 - 2019 Chapel Hill Expert Survey Trend File. Chapel Hill, NC: University of North Carolina. Version 1.2. Retrieved from chesdata.eu.

Bargain, O. \& Aminjonov, U. (2020). Trust and Compliance to Public Health Policies in Times of COVID-19. Journal of Public Economics, 192, 104316. doi: 10.1016/j.jpubeco. 2020.104316 .

Bjørnskov, C. (2020). Did Lockdown Work? An Economist's Cross-Country Comparison. Retrieved from SSRN: https://ssrn.com/abstract=3665588, 1-12, doi: 10.2139/ssrn. 3665588.

Bjørnskov, C. \& Voigt, S. (2018). Why Do Governments Call a State of Emergency? On the Determinants of Using Emergency Constitutions. European Journal of Political Economy, 54, 110-123. doi: 10.1016/j.ejpoleco.2018.01.002.

Bjørnskov, C. \& Voigt, S. (2020). This Time Is Different? On the Use of Emergency Measures During the Corona Pandemic. ILE Working Paper Series. No. 36.

Boin, A., 't Hart, P., Stern, E. K. \& Sundelius, B. (2016). The Politics of Crisis Management. Cambridge: Cambridge University Press.

Bouhon, F., Jousten, A., Miny, X. \& Slautsky, E. (2020). L’État belge face à la pandémie de COVID-19: esquisse d'un régime d'exception. Courrier hebdomadaire du CRISP, 2020/1, $n^{\circ}$ 2446, 5-56.

Capano, G., Howlett, M., Jarvis, D. S. L., Ramesh, M. \& Goyal, N. (2020). Mobilizing Policy (In)Capacity to Fight COVID-19: Understanding Variations in State Responses. Policy and Society, 39(3), 285-308. doi: 10.1080/14494035.2020.1787628.

Cheng, C., Barceló, J., Spencer, H. A., Kubinec, R. \& Messerschmidt, L. (2020). COVID-19 Government Response Event Dataset (CoronaNet v. 1.0). Nature Human Behaviour, 4(7), 756-768. doi: 10.1038/s41562-020-0909-7.

Decker, N. D. (2020, juin 10). Les Belges jugent la crise : Le problème, c'est la méfiance (sondage). Site-LeVif-FR. Retrieved from www.levif.be/actualite/belgique/les-belges-jugentla-crise-le-probleme-c-est-la-mefiance-sondage/article-normal-1298053.html.

Driessen, M. \& Heinkade, P. (2021). Februari peiling \#2 I\&O Research. 13. 
Egger, C., Magni Berton, R., Roché, S. \& Aarts, C. W. A. M. (2021). I Do It My Way: Understanding Policy Variation in Pandemic Response Across Europe. Frontiers in Political Science. doi: 10.31219/osf.io/mscb8 .

Faniel, J. \& Sägesser, C. (2020). La Belgique entre crise politique et crise sanitaire (marsmai 2020). Courrier hebdomadaire du CRISP, 2020/2, $n^{\circ}$ 2447, 5-46.

Grote Coronastudie. (2020). Resultaten. University of Antwerp. Retrieved from https:// uantwerpen.be/nl/projecten/corona-studie.

Hale, T., Angrist, N., Goldszmidt, R., Kira, B., Petherick, A., Phillips, T. ... Tatlow, H. (2021). A Global Panel Database of Pandemic policies (Oxford COVID-19 Government Response Tracker). Nature Human Behaviour, 5(4), 529-538. doi: 10.1038/ s41562-021-01079-8.

Honigsbaum, M. (2020). Epidemics Have Often Led to Discrimination Against Minorities This Time Is No Different. The Conversation. Retrieved from https:// theconversation.com/epidemics-have-often-led-to-discrimination-against-minoritiesthis-time-is-no-different-140189 .

Hooghe, L., Marks, G., Schakel, H. A., Chapman Osterkatz, S., Niedzwiecki, S. \& ShairRosenfield, S. (2016). Measuring Regional Authority, A Postfunctionalist Theory of Governance, Volume 1. Oxford: Oxford University Press.

Journal Officiel. (2020). LOI n 2020-290 du 23 mars 2020 d'urgence pour faire face à l'épidémie de COVID-19. Retrieved from www.legifrance.gouv.fr/jorf/id/ JORFTEXT000041746313.

Kantar Survey. (2020). COVID-19 Barometer. Retrieved from www.kantar.com/ campaigns/covid-19-barometer.

Krause, W., Lehmann, P., Lewandowski, J., Matthieß, T., Merz, N., Regel, S. \& Werner, A. (2020). Manifesto Corpus. Version: 2020. Berlin: WZB Berlin Social Science Center.

Lodge, M. \& Wegrich, K. (eds.). (2012). Executive Politics in Times of Crisis. Executive politics and governance. Palgrave Macmillan, Basingstoke, UK.

Louwerse, T., Sieberer, U., Tuttnauer, O. \& Andeweg, B. R. (2021). Opposition in Times of Crisis: COVID-19 in Parliamentary Debates. West European Politics. doi: 10.1080/01402382.2021.1886519.

Mickler, T. A. (2017). Committee Autonomy in Parliamentary Systems - Coalition Logic or Congressional Rationales? The Journal of Legislative Studies, 23(3), 367-391. doi: 10.1080/13572334.2017.1359941.

Migone, A. R. (2020). The Influence of National Policy Characteristics on COVID-19 Containment Policies: A Comparative Analysis. Policy Design and Practice, 3(3), 259-276. doi: $10.1080 / 25741292.2020 .1804660$.

Moury, C. \& Timmermans, A. (2013). Case Study Three: The Netherlands. In C. Moury (Ed.), Coalition Government and Party Mandate. How Coalition Governments Constrain Ministerial Action (pp. 70-72). London/New York: Routledge.

Otjes, S. \& Louwerse, T. (2021). Derde keer op de evenwichtsbalk. Parlementair stemgedrag tijdens Rutte III. In J. Schinkelshoek \& G. Voerman (Eds.), 'Niet stoffig, toch?' Terugblik op het kabinet-Rutte III (pp. 55-70). Den Haag: Montesquieu Instituut.

Raad voor het Openbaar Bestuur. (2017). Het regeerakkoord als startdocument. Basis voor responsief overheidsbeleid. Retrieved from www.raadopenbaarbestuur.nl/binaries/raadopenbaar-bestuur/documenten/publicaties/2017/01/22/het-regeerakkoord-alsstartdocument/Het_regeerakkoord_als_startdocument_Signalement_201701.pdf.

RIVM. (2021). Vertrouwen in Nederlandse aanpak. Retrieved from www.rivm.nl/ gedragsonderzoek/maatregelen-welbevinden/communicatie-en-vertrouwen.

Roché, S. (2020). Violences policières, Esprit, January, 15 pages. 
Rozell, M. J. \& Wilcox, C. (2020). Federalism in a Time of Plague : How Federal Systems Cope With Pandemic. The American Review of Public Administration, 50(6-7), 519-525. doi: $10.1177 / 0275074020941695$.

Schmitt, C. (1922),. Théologie politique (1988 ed.). Paris: Gallimard.

Survey Kantar - Le Vif/l'Express - Knack - LN24. (18-25 May 2020). Les Belges jugent la crise. Representative sample of 1021 people, margin of error 3.1\%. Retrieved from www.ln24.be/2020-06-09/les-belges-jugent-la-crise-la-claque-pour-de-block-wilmesconvainc-emmanuel-andre.

Terpstra, J., de Maillard, J., Salet, R. \& Roché, S. (2021). Policing the Corona Crisis: A Comparison Between France and the Netherlands. International Journal of Police Science and Management, 1-14. doi: 10.1177/1461355720980772.

Torcal, M. (2017). Political Trust in Western and Southern Europe. In S. Zmerli \& T. W. G. van der Meer (Eds.), Handbook on Political Trust (pp. 418-439). Cheltenham: Edward Elgar Publishing.

Tsebelis, G. (2002). Veto Players: How Political Institutions Work. New Haven: Princeton University Press.

Vries, de F. (2000). De Staatsrechtelijke positie van de Eerste Kamer. Deventer: Kluwer.

Zalc, J. \& Maillard, R. (June 2020). Uncertainty/EU/Hope Public Opinion in Time of COVID-19. Public Opinion Survey Commissioned by the European Parliament. ISBN: 978-92-846-6791-8.

Zanghellini, A. (2016). The Foundations of Rule of Law. Yale Journal of Law and Humanities, 28(2), 213-240. 